Article

\title{
Time-Varying Influences of Oil-Producing Countries on Global Oil Price
}

\author{
Peter Y. Jang * (1D) and Mario G. Beruvides \\ Department of Industrial, Manufacturing, and Systems Engineering, Texas Tech University, Box 43061, Lubbock, \\ TX 79409-3061, USA; mario.beruvides@ttu.edu \\ * Correspondence: peter.y.jang@ttu.edu
}

Received: 10 January 2020; Accepted: 5 March 2020; Published: 17 March 2020

\begin{abstract}
This paper aims to investigate the time-varying influences of major crude oil-producing countries on Brent oil prices, with seven-panel data over the observation years of 1998 to 2018. We create seven panels with 36 monthly data for each and estimate the contributions of individual producing countries to oil price changes with a multivariate regression technique of ordinary least squares. Most existing researches have focused on identifying relationships among oil price, market fundamental factors, macroeconomic variables, and geopolitical events in broad perspectives. However, this paper undertakes a longitude/panel analysis of nine oil producers' influences, with the Organisation for Economic Co-operation and Development (OECD) consumption and the U.S. Dollar Index (USDX) on oil prices in each panel and intends to identify which producers have statistically significant influencing weights on oil prices. We believe that this research contributes to the body of knowledge in better understanding the relative impacts of major oil-producing countries. Results show empirical evidences that the Organization of the Petroleum Exporting Countries (OPEC) production stayed as the greatest negative influence on the oil price in the periods of Panel 2 (2001-2003) and Panel 7 (2016-2018) only, while the U.S. Dollar Index took over the OPEC's influencing role in most of the other periods, followed by Iran, the U.S., and China.
\end{abstract}

Keywords: oil producers; oil price; time-varying influence; oil market fundamentals; oil price fluctuation

\section{Introduction}

Crude oil is a critical source for economic growth and further industrialization, and the industrialized nations import a significant portion of oil from the Persian Gulf [1]. Oil accounts for 33\% of global energy consumption and trades in US dollars per barrel of 42 US gallons [2].

Major benchmarks of crude oil include the West Texas Intermediate (WTI) in the U.S., the Brent Blend and the North Sea in Europe, and the Organization of the Petroleum Exporting Countries (OPEC) Reference Basket (ORB) of fourteen blends. While the WTI and Brent benchmark prices are for oil exports to the Atlantic Basin [3], the Brent crude price index is a benchmark to set oil prices for $70 \%$ of world oil transactions [4]. Figure 1 presents a map of global crude oils and their positioning by API (American Petroleum Institute) gravity, a measure of liquid petroleum density, and sulfur content. The crude oil with high API gravity has low density and light weight, while the oil with high sulfur content is called a sweet oil $[3,5,6]$. The WTI oil is very sweet high-quality, and the index is the most famous benchmark in the U.S. and the Western Hemisphere, with its future's products traded on the New York Mercantile Exchange (NYMEX). The Brent oil is not as light as WTI but still a high grade from fifteen oil fields in the North Sea. 


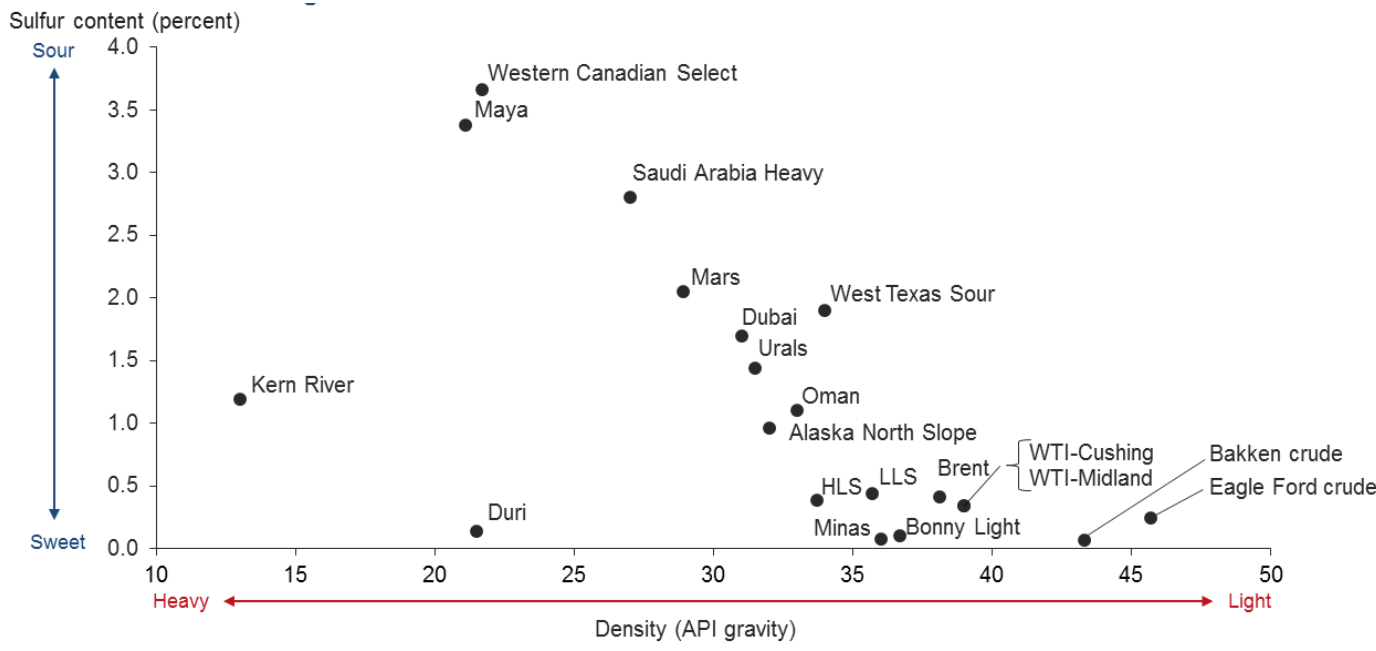

NOTES: WTI refers to West Texas Intermediate crude; LLS and HLS refer to Louisiana Light Sweet and Heavy Louisiana Sweet, respectively. API refers to American Petroleum Institute.

Figure 1. Crude oil is not a homogenous resource. Source: Reprinted with permission from Federal Reserve Bank of Dallas [6].

In 2018, top three crude oil producing countries were the U.S., Russia, and Saudi Arabia, producing over 10 million barrels a day each, followed by Iraq, Canada, Iran, and China, that produce about 4 million barrels a day each (Figure 2). The top three producers accounted for $39 \%$ of daily world production, comparable to OPEC's $41 \%$, while the top ten producers had a $69 \%$ share with 57 million barrels [7].

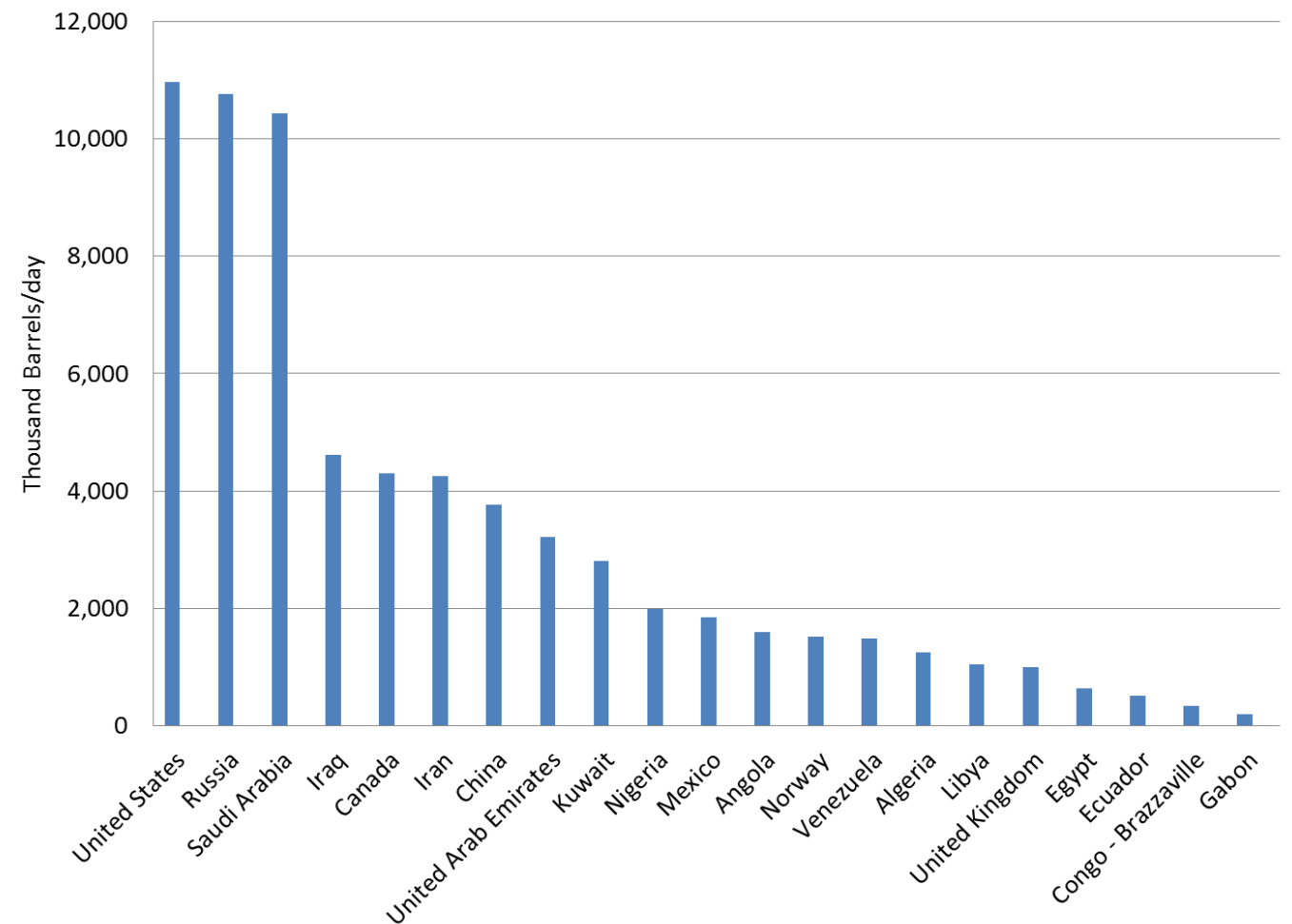

Figure 2. Major crude oil producing countries by production volume in 2018. Data source: U.S. Energy Information Administration [7]. 
Global oil market has the structure of two major player categories: low-cost public producers and highly competitive private producers [8]. Public producers include national oil companies (NOCs), including OPEC and non-OPEC-producers (Russia and Mexico), and account for $60 \%$ of global oil production. As such, global oil markets are heavily political, far away from a competitive market [9], and $94 \%$ of world proven reserves are controlled by governments [2]. There are some questions how long OPEC, the most influencing oil producing organization, would last as an international cartel given the historical examples of other commodity cartels, International Tin Association (1954 to 1985), and International Coffee Association (1962 to 1989) [10].

The global oil market has invisible hands of suppliers and consumers affecting oil prices. Oil price behavior, in a social system, may follow one of several fundamental modes, exponential growth, goal seeking, and oscillation, affected by a simple feedback structure of the components as suggested by a systems theory [11]. Other modes of nonlinear behavior include S-shaped growth, S-shaped growth with overshoot and oscillation, and overshoot and collapse.

In both academia and industry, it has been the subject of debate, what intrinsically drives crude oil prices. Figure 3 is a behavior over time (BOT) chart of annual prices of Brent spot and WTI spot from 1997 to 2018. The price level of U\$20 per barrel in 1997 increased to U\$100 in 2008 and settled down at $U \$ 65$ to $U \$ 70$ in 2018 . Three explanations are postulated for the causes of the price declines: those associated with oversupply, those associated with under-consumption even with under-supply, and the future oil markets' bearish views of future market fundamentals and sell-now executions [8].

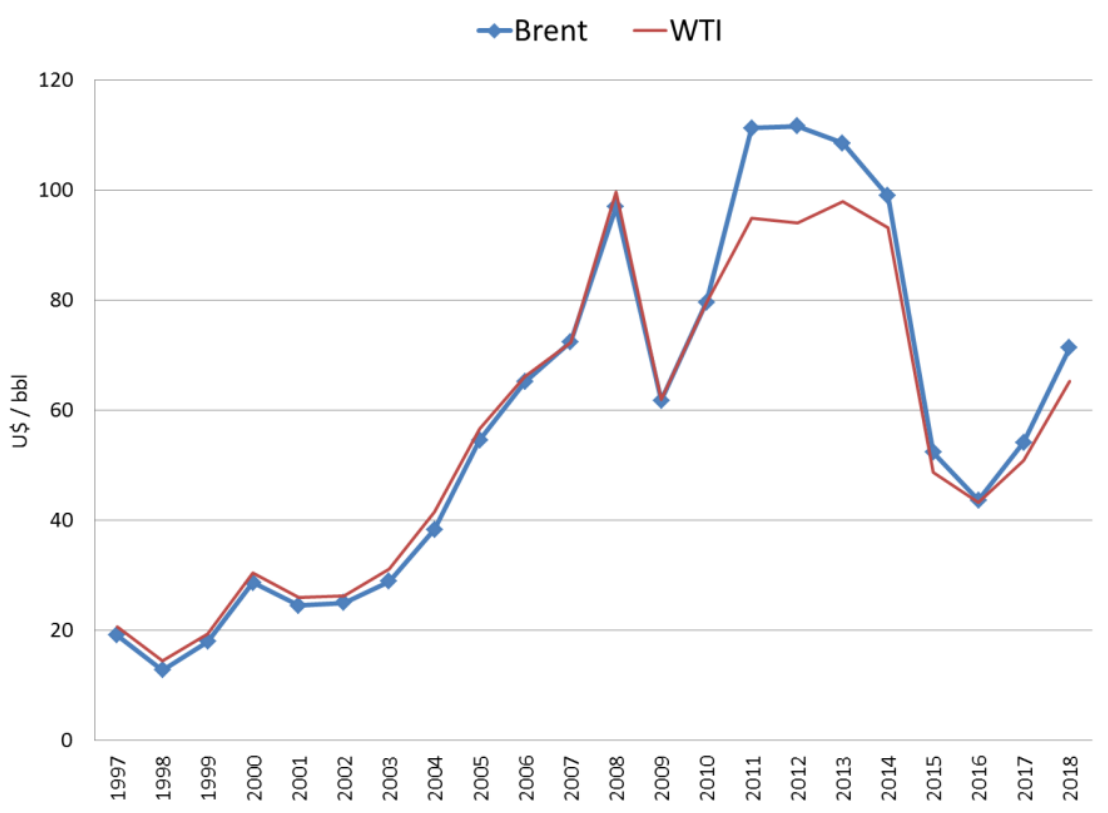

Figure 3. Crude oil benchmark annual prices (Brent and West Texas Intermediate (WTI) spot, nominal) -1997 to 2018. Data source: U.S. Energy Information Administration [12].

The period of 1973-1996 was quoted as "the age of OPEC" and the years of 1997 to present as a new industrial age outside OPEC [13], which describes the dominant power of OPEC through the mid-1990s and then emerging new forces in the late 1990s. Previous studies focused on identifying relationships between oil price and macro variables: relationship with supply factors $[2,8,10,14]$, demand factors [15,16], macroeconomic variables [2,17], event-driven factors [9], and the consequences of high/low oil prices [18].

Oil discovery and technical improvement takes time to keep a market at an equilibrium state, and multiple time scales, short-term, mid-term, and long-term are more appropriate for analysis [19]. In a 
similar context, this paper takes the approach of multiple time panels, away from a traditional single time horizon.

This paper aims to investigate the influencing weights of major crude oil-producing countries on the Brent oil price in seven individual panels with 36 monthly data each. Nonproduction-related variables are petroleum consumption and the U.S. Dollar Index (USDX). This paper takes longitude/panel study approaches, from 1998, a year after 1997, a starting year of "the new industrial era" to 2018, and intends to provide empirical evidence which oil-producing countries were relatively more influential to the Brent oil price in each of the time-varying panels. As this is the first paper with a unique approach in oil market analysis, we believe that it provides better understanding of dynamic roles of major oil-producing countries in each defined period. This paper is organized as follows: Section 2: review of the current state of the art, Section 3: data and methodology, Section 4: results and discussion, and Section 5: conclusions and policy implications.

\section{Review of the Current State of the Art}

A review of literatures resulted in a number of studies that attempted to explain the fluctuations of crude oil prices, in terms of historical overviews, supply side (OPEC and non-OPEC), demand side, macroeconomic factors, price decline factors, oil future's market and speculation, event-driven factors, impact of oil prices on producers and consumers economies, and consequences of oil price shocks.

\subsection{Historical Overview}

When the first oil crisis took place in 1973, the imported crude oil price to the U.S. quadrupled in 1973/1974, and the West Texas Intermediate (WTI) rose from U\$4.31 in September 1973 to U\$10.11 per barrel in January 1974. Prior to 1973, oil price fluctuations were the results of shift in demand or global economic expansion [20], but since the early 1980s, the fluctuation has reflected the disruption of the flow, exogenous political events, war, revolution, and OPEC coalition [13]. Figure 4 presents a historical overview of oil prices, with geopolitical and economic events in a chronological order, from 1970 to 2015 [2].

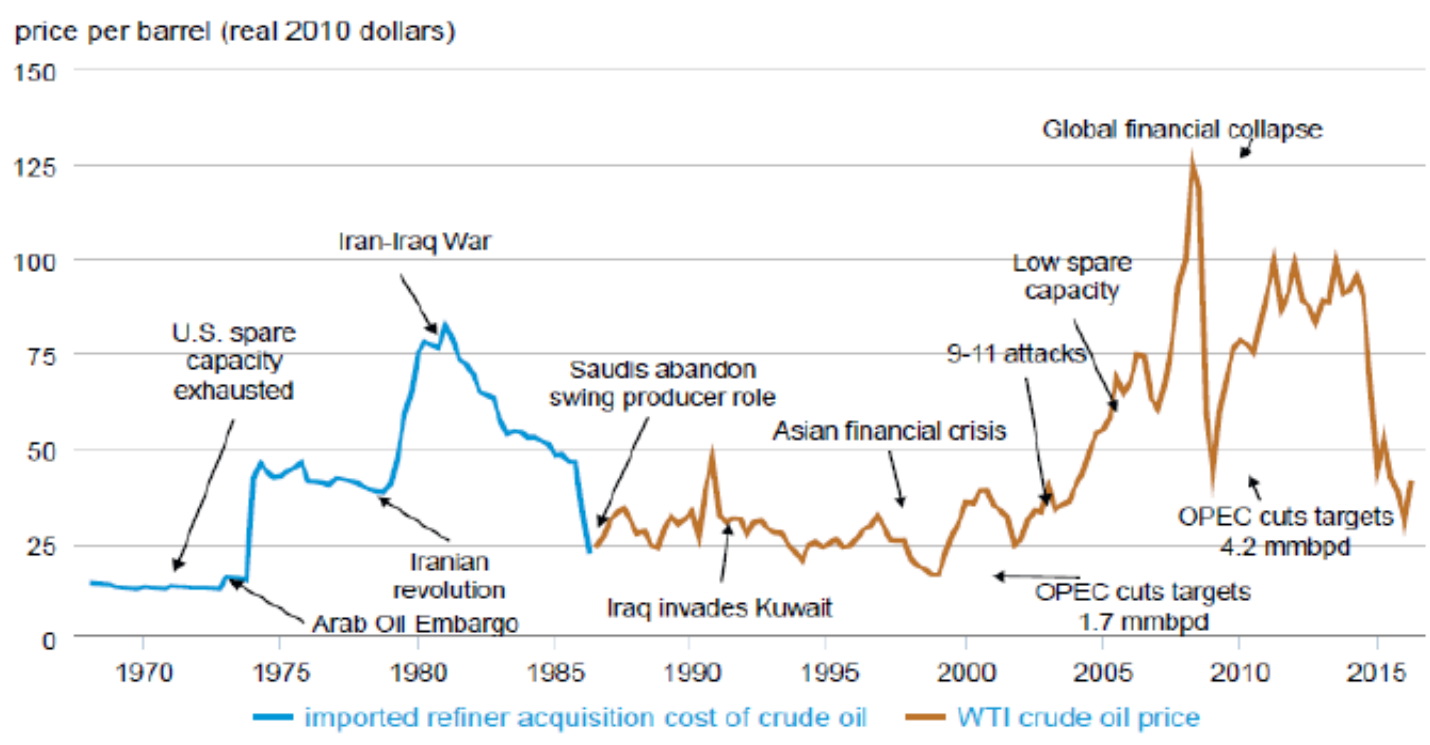

Figure 4. Geopolitical and economic effects on crude price. Source: Reprinted with permission from Solomon Adjei Marfo [2].

Baumeister \& Kilian (2016) [20] describes four main episodes in the past four decades: the periods of the 1973/1974 oil crisis, the 1979/1980 crisis with Iran revolution, 1980s/1990s with Iran-Iraq war, and 2003/2008 with global financial crisis. The first episode was the Arab oil embargo where OPEC 
cut production by $5 \%$ and then an additional $25 \%$. The second episode was the Iranian Revolution, resulting in oil price skyrocketing to U\$40 per barrel in April 1980, from U\$15 in September 1978.

The third episode period 1980s/1990s was a result of a large exogenous supply disruption, and subsequently, non-OPEC countries, Mexico, Norway, and the U.K., responded by transforming themselves to oil producers. In the aftermath, OPEC's market share of 53\% in 1973 dropped to $43 \%$ in 1980 and then $28 \%$ in 1985 . Approximately 10 years later, the WTI price plummeted to U\$25 per barrel in 1996 due to the Asian financial crisis and then down to U\$11 per barrel in 1998. The global financial crisis occurred and ran in parallel during the fourth episode in 2003-2008, when the WTI oil traded in the wide range of U\$28 to 134 per barrel. Demand growth in India and China contributed to the rising prices throughout the mid-2008, but the global financial crisis led to a sharp drop in demand, pushing down the price to U\$39 per barrel in February 2009.

\subsection{Supply Side-OPEC}

OPEC, founded in 1960 by five oil-producing nations, and with fourteen members as of August 2019 [21], accounts for an estimated $42 \%$ of global oil production and $73 \%$ of world oil proven reserves. OPEC started setting a target production in 1980 for each of its members to maintain stable oil prices [2].

Major producers prior to 1970 were seven western companies called "Seven Sisters": Anglo-Persian Oil Co, Gulf Oil, Standard Oil of California, Texaco, Royal Dutch Shell (RDS), Standard Oil of New Jersey, and Standard Oil of New York [22], and these producers now account for 5\% of global oil reserves [2].

Oil spare production capacity could be a factor to affect oil price volatility. OPEC uses its spare production capacity to stabilize the oil market. Four core producers, Saudi Arabia, Kuwait, Qatar, and U.A.E., successfully balanced oil market and reduced price volatility to one-half of the normal level by adjusting production to offset supply and demand shocks and by maintaining the volume of spare capacity at $85 \%$ as swing producers [14].

In the "age of OPEC" prior to 1997, OPEC production quantity was accompanied by non-OPEC production quantity; for example, in 1982-1985, OPEC reacted to lower real oil prices [23]. In the "new industrial age" when OPEC's market power was getting weakened [13], OPEC production quantity just sustained the global production/consumption for GDP growth.

\subsection{Supply Side-Non-OPEC}

Small producing countries, each with a less than $5 \%$ share of world oil output, increased their combined share from 59.4\% to 65.1\% between 1995 and 2010 [24]. The small producers include Angola and Algeria in Africa, Indonesia, and Malaysia in Asia, and Mexico and Venezuela in South America, and Norway in Europe. They responded to the changes in the world oil market, and their decisions indicated that there was a strong relationship between their production levels and changes in oil consumption but with a lower relationship between the production level and change in prices.

Growth of the U.S. shale oil production is notable. The shale production was close to zero in 2008 but grew to 4.25 million barrels a day in 2016, standing with a $48 \%$ share of the U.S. oil production and $5 \%$ of the global production [10]. At the end of 2018, the U.S. shale production stood at 6 million barrels a day, accounting for $57 \%$ of the nation's total production. The shale production also contributed to an increase of the U.S.'s global market share to $13 \%$ in 2018, up from $8 \%$ in 2000 , potentially influencing the oil price collapses in the recent decade [25].

Shale oil production can respond to changes in oil prices much quicker than a traditional oil technology, with the competitive edges of improvement in fracking technology and its lower extraction costs. The U.S. shale oil development may be analogous to a structural change in systemic processes. Kuhn (2012) describes three ways for a paradigm to respond to crises: one, proving to solve the crisis, two, giving up with no solution and leaving for next generations, and three, ending up with a new accepted paradigm after the battle [26]; the shale oil case belongs to the third way. 


\subsection{Demand Side}

On the oil consumption side, the most influential driver is demand for refined oil products, and OECD accounts for $50 \%$ of world petroleum demand [2]. When the refining capacity is lost, it would affect the oil demand side. Notably, the Arab embargo in 1973 disrupted the oil supply and pushed up the market price, resulting in depressing the U.S. and OECD demand by $2-4 \%$ per year in 1974 and 1975 [12].

Oil price rise in 2004-2008 is also the subject of debate. While a price rise is viewed in association with increased demand, another view is that oil price is more sensitive to supply as production approaches its capacity [15]. Thus, refining utilization rates, OPEC capacity utilization, and oil future's markets affect oil price. Oil price movements may exert negative impacts on gross domestic product (GDP), consumer price index (CPI), and unemployment in oil consuming countries, in particular, based on economic data collected from 26 OECD countries [16].

\subsection{Macroeconomic Factors}

Economic growth and energy investments lead to more available oil supply, as well as oil demand. As crude oil trades in US dollars in global markets, the depreciation of US dollars leads to more demand for oil, and vice versa [2], indicating negative correlations between oil demand and the US dollar strength. Other macroeconomic factors may include future oil markets, speculators, hedgers, brokers, and exchanges available to the global players.

There are meaningful relationships between oil price and more extensive macroeconomic variables, such as global industrial production, prices, and interest rate [17]. Among five countries in the study, the global macro factors were main drivers for the U.S., Europe, and China but minor ones for Japan and India. Other studies also examined relationships between oil price and macroeconomic variables [27-29].

\subsection{Price Decline Factors}

Price decline in 2007-2008 was a good example of formation and collapse of an oil price bubble, going through combined effects of stagnant oil supply, unexpected economic growth in India and China, low interest rate, a weak U.S. dollar, and a consequent sharp spike in oil prices [30]. This behavior is similar to a mode of overshoot and collapse in a social system [11].

The World Bank lists causal factors to sharp drops in oil prices: supply and demand, changes in OPEC objective, geopolitics, the U.S. dollar appreciation, speculative demand and investment management, relative contribution of supply and demand, and oil price outlook [10]. Fundamental oil supply and demand set the conditions for a long-term trend in price, but in the short-term, market sentiment and expectation led to price fluctuations.

The World Bank reported that the oil price drop in June 2014 was significant but not an unprecedented event, as a 30\% price decline were observed in five cases over a seven-month period in history [10]. Those five periods are 1985-1986 with strong production from non-OPEC, 1990-1991 with the U.S. economic recession, 1997-1998 with Asian financial crisis, 2008-2009 with global financial crisis, and the latest, June 2014-January 2015 with a supply glut from unconventional sources since mid-2014. In November 2014, OPEC changed its policy and abandoned an objective to set a target price.

\subsection{Oil Future's Market and Speculation}

Crude oil future's market usually reflects the expectation of market fundamentals. Unexpected disruption in the oil market comes with large regression residuals, and the derivative paper markets contain information on the magnitude and duration of major market disruption [31]. Empirical results are derived from investigating price volatility of Brent oil (2000-2014) in relationship with the term structure of option-based implied volatilities and global macro-economy; physical market fundamentals (OPEC surplus output, capacity, and storage); and equity volatility index (VIX). 
On a short run, if oil market is not price-sensitive, or relatively inelastic, then oil investment would be slow to take place [32]. Oil prices spiked in the period of 2000 to 2010, and one of the explanations was that speculative pressure exerted influence on the prices of the storable commodities.

\subsection{Event-Driven Factors}

When political instability is prevailing in any of the oil-producing countries, oil production capacity may be disrupted and reduce available supply [2]. Roles of political economic news in oil pricing are also important [9].

The Arab embargo in the early 1970s led to technology advancements among non-OPEC nations to secure oil resources, resulting in active developments of unconventional and offshore oil sources, with the North Sea in the 1970s and the Gulf of Mexico in the 1980s. The shale oil, a tight rock formation, has a shorter life cycle of 2.5 to 3 years from shale development to full extraction and contributes to the global supply with low capital costs [10].

Wars or political tensions may disrupt oil supply to the markets, but, by their models, show no direct effect [33]. As demand is inelastic to price change, economic activity is the most significant factor to affect demand. Major wars/political events in oil markets include Arab-Israeli War (1973), Persian Gulf War (1991), Operation Desert Fox (1998), Iraq War (2003-2011), Arab Spring (2011), global financial crisis (2008), and European debt crisis (2010).

\subsection{Impact of Oil Prices on Producers' and Consumers' Economies}

Impacts of oil price shocks vary with on oil producers and oil-consuming economies [29]. Among twelve economies analyzed for a period of 1995 to 2006, oil producers, Russia and Canada, benefited from oil price shocks, while oil importers found their economic activities suffer a slowdown in their GDP. The largest negative effects from the shocks were present in Japan, China, the U.S., Finland, and the Switzerland.

When oil price shocks take place at the markets, their consequences include shocks to key supply chains, global economic activities, national accounts, inflation, and searches for non-oil sources [10,34]. The price also shocks inflation in low oil-dependency and high oil-dependency countries [18].

There is a strong relationship between oil price shocks and the U.S. recessions [35], and Canada is affected by U.S. domestic monetary policies. Foreign disturbances, such as innovations and the U.S. interest rate, leads to significant inflation in the Canadian economy [36]. Due to the oil price volatility, even oil producers find it hard to meet their government expenditure. Bahrain implemented a policy in the late 1970s to diversify their economy by attracting finance investment in the state [37]. Oil price fluctuations also affected economic activities of small oil-producing countries, Trinidad and Tobago [38], and fiscal policies in oil-exporting countries [39].

\section{Data and Methodology}

\subsection{Data}

Oil price is the response (dependent) variable or a simple average monthly spot price of Brent crude oil (denoted here as BRENT), published by the U.S. Energy Information Administration (EIA). The Brent crude oil price is selected as a global oil proxy price, because it represents a benchmark price for about $70 \%$ of the global oil transactions [4]. The period for analysis is 21 years, or 252 months, from 1998 to 2018, with 1997 being the start of "the new industrial age" in the global oil market, according to Hamilton (2013) [13]. The base unit is U\$ per barrel.

Explanatory (independent) variables are monthly crude oil production data by country collected from EIA, and data for analysis covers the same period of 1998 to 2018. Producing countries for analysis are nine major countries, including five OPEC and four non-OPEC countries, based on their production ranks in 2018. They are United States (US), Russia, Saudi Arabia, Iraq, Canada, Iran, China, UAE, and Kuwait. OPEC is also included for analysis, due to its heavy share (41\%) of the global production in 
2018. In this paper, the capitalized names of explanatory variables represent the individual production quantity of the country or organization. The base unit for oil production is one thousand barrels per day.

Two non-production related variables are selected besides the explanatory variables. Monthly petroleum consumption data for OECD is collected from EIA and used as a proxy of world petroleum consumption, since the Old World consumption data is not available on a monthly level. The OECD's share of the world consumption accounts for an average of 56\% in the years 1998-2018. OECDCON represents monthly petroleum consumption of its 36 members. Its unit is also one-thousand barrels per day. Another non-production-related variable is the monthly Trade Weighted U.S. Dollar Index (USDX), a macroeconomic variable, with January 1997 as a base month. This index represents the strength of the U.S. dollar. As oil price trades in U.S. dollars, this index influences oil demand and oil price. For example, when the U.S. Dollar Index is strong (high), then consumers tend to consume oil less. The data source is the Federal Reserve Bank of St. Louis (https://alfred.stlouisfed.org). The unit is dimensionless.

Each panel covers a 36-month period, with seven panel data over the 21-year period, with an assumption that additional production may be possible to react to a need for additional supply with a 3-year period. Conventional oil development takes 5-10 years [40], but the shale oil development requires a shorter cycle [41].

The response variable and explanatory variables are all transformed to a natural logarithm format, or $\mathrm{LN}$, so a percentage change in the response variable may be estimated with respect to a percentage change in one exploratory variable, if they are statically significant at the $0.1(10 \%)$ level.

\subsection{Methodology}

In the whole period and each of seven panel period data, coefficients of variation (CV) are first calculated to understand a degree of fluctuations of each variable. Coefficient of variation (CV) is defined as a ratio of the standard deviation to the mean of a variable, indicating a common measure of the magnitude of variability for comparison among the variables. This measure helps identify potential variables that may influence more on the response variable, Brent oil price.

In each of seven panel data, a multivariate regression technique with ordinary least squares is used as a main tool to measure the coefficient estimates of explanatory variables, and the coefficient estimates will be compared to determine influencing weights among the variables. If $p$-value of the regression parameter estimates of any explanatory variables is greater than $10 \%$, the variables will be excluded from comparisons of the coefficient estimates, because they are not statistically significant at the level.

There are a total of eight runs of regression models in this analysis; that is, one for the whole period and seven for seven panels. Each of the eight runs has individual summaries of parameter estimates, and then the coefficient estimates of statistically significant explanatory variables are compared to measure influencing weights.

Equation for multivariate regression parameter estimation in each of panels is:

$$
\begin{aligned}
& \text { LN_BRENTt }=\alpha_{t}+\text { LN_OPEC }_{t}+\beta_{1} \times \text { LN_US }_{t}+\beta_{2} \times \text { LN_RUSSIA } t+\beta_{3} \times \text { LN }_{t} \text { SAUDI } t \\
& +\beta_{4} \times \text { LN_IRAQ }_{t}+\beta_{5} \times \text { LN_CANADA }_{t}+\beta_{6} \times \text { LN_IRAN }_{t}+\beta_{7} \times \text { LN_CHINA }_{t}+\beta_{8} \times \\
& \mathrm{LN}_{-} \mathrm{UAE}_{\mathrm{t}}+\beta_{9} \times \mathrm{LN}_{-} \mathrm{KUWAIT}_{\mathrm{t}}+\beta_{10} \times \mathrm{LN}_{-} \mathrm{OECDCON} \mathrm{t}+\beta_{11} \times \mathrm{LN}_{-} \mathrm{USDX}_{\mathrm{t}}+\varepsilon_{\mathrm{t}}
\end{aligned}
$$

where

Response variable:

LN_BRENT ${ }_{t}$ : natural log of monthly Brent oil price (BRENT) at a month $\mathrm{t}$;

Explanatory variables:

LN_CANADA $A_{t}$ : natural log of monthly Canada production (CANADA) at a month $\mathrm{t}$;

LN_CHINA $\mathrm{t}_{\mathrm{t}}$ : natural log of monthly China production (CHINA) at a month $\mathrm{t}$; 
LN_IRAN $\mathrm{t}_{\mathrm{t}}$ : natural log of monthly Iran production (IRAN) at a month $\mathrm{t}$;

LN_IRAQ : natural log of monthly Iraq production (IRAQ) at a month $t$;

LN_KUWAIT $\mathrm{t}$ : natural log of monthly Kuwait production (KUWAIT) at a month $\mathrm{t}$;

LN_OECDCON $\mathrm{t}_{\mathrm{t}}$ : natural log of monthly OECD petroleum consumption (OECDCON) at a month $\mathrm{t}$;

LN_OPEC $\mathrm{t}$ : natural log of monthly OPEC production (OPEC) at a month $\mathrm{t}$;

LN_RUSSIA $\mathrm{t}_{\mathrm{t}}$ : natural log of monthly Russia production (RUSSIA) at a month $\mathrm{t}$;

LN_SAUDI $:$ natural log of monthly Saudi Arabia production (SAUDI) at a month t;

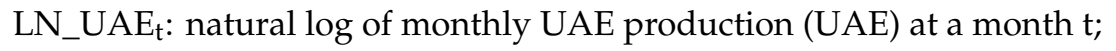

LN_US ${ }_{t}$ : natural log of monthly U.S. production (US) at a month $t$;

LN_USDX $\mathrm{t}_{\mathrm{t}}$ natural log of monthly U.S. Dollar Index (USDX) at a month $\mathrm{t}$.

\section{Results and Discussion}

Starting with a summary for the whole period of 1998 to 2018, all the variables, responses, and explanations are summarized in the tables of descriptive summary statistics in each panel, followed by a summary table of parameter estimations. Units of each variables are also displayed on Table 1, and the units stay the same in all tables and figures of this paper, unless otherwise specified.

Table 1. The whole period (1998-2018): summary statistics.

\begin{tabular}{|c|c|c|c|c|c|c|c|c|}
\hline Variable & $\mathbf{N}$ & Mean & Median & Std Dev & $\mathrm{CV}$ & Min & $\operatorname{Max}$ & Range \\
\hline BRENT (U\$/bbl) & 252 & 59.87 & 56.36 & 32.66 & 54.54 & 9.82 & 132.72 & 122.90 \\
\hline CANADA (1000 bbl) & 252 & 2800 & 2601 & 711 & 25.41 & 1832 & 4520 & 2688 \\
\hline IRAN (1000 bbl) & 252 & 3810 & 3900 & 385 & 10.10 & 3018 & 4624 & 1606 \\
\hline IRAQ (1000 bbl) & 252 & 2746 & 2515 & 963 & 35.05 & 53 & 4815 & 4762 \\
\hline KUWAIT (1000 bbl) & 252 & 2425 & 2500 & 307 & 12.66 & 1785 & 2951 & 1166 \\
\hline RUSSIA (1000 bbl) & 252 & 8949 & 9423 & 1503 & 16.80 & 5707 & 11,051 & 5344 \\
\hline SAUDI (1000 bbl) & 252 & 9138 & 9220 & 875 & 9.58 & 7210 & 11,045 & 3835 \\
\hline UAE (1000 bbl) & 252 & 2680 & 2602 & 363 & 13.55 & 2050 & 3451 & 1401 \\
\hline US (1000 bbl) & 252 & 6605 & 5804 & 1752 & 26.52 & 3974 & 11,961 & 7987 \\
\hline USDX (base = 1997) & 252 & 112 & 114 & 10 & 8.70 & 95 & 130 & 35 \\
\hline
\end{tabular}

\subsection{The Whole Period: $1998-2018$}

Average Brent oil spot price was U\$59.87 per barrel during the whole observation period of 21 years, with its coefficient of variation (CV) the highest (54.54) among all variables (Table 1). Producing countries with high CVs for the 21-year period are Iraq (35.05), the U.S. (26.52), Canada (25.41), and Russia (16.80). These high-CV countries could be notable contributors to such a volatile Brent oil price. Summary statistics of all the variables for each of the panels will be discussed separately.

For the whole period of 1998 to 2018, parameter estimates by the multivariate regression to explain the response variable LN_BRENT are summarized on Table 2. Major explanatory variables with a statistical significance level of $0.1 \%$ or $10 \%$ are LN_USDX, LN_RUSSIA, LN_SAUDI, LN_CHINA, LN_KUWAIT, LN_IRAN, and LN_IRAQ. Among the significant variables, USDX (the U.S. Dollar Index), the only macroeconomic variable in this analysis, is the greatest influencing factor in the whole period, with one percent change in USDX resulting in a 3.68\% decline in the Brent price, while one percent change in production from Kuwait, China, and Iran negatively affected the price by $1.56 \%$, $1.5 \%$, and $0.63 \%$, respectively.

Meanwhile, production of other significant producers, Russia, Saudi Arabia, and Iraq, co-moved with the price, or one percent change in production leading to $2.96 \%, 2.46 \%$, and $0.12 \%$, respectively. These co-move coefficient estimates are in contradiction with the basic economic theory; a price negatively correlates with supply quantity [10]. Some of the interpretations for this co-moving supply-price relationship are that an information asymmetry may exist due to a production location 
being remote from a market place that the Brent oil index is based on, or the producer's change in supply did not simply change oil price direction.

Table 2. The whole period (1998-2018): LN_BRENT prediction-parameter estimation.

\begin{tabular}{ccccc}
\hline Variable & Estimate & Std Error & $\mathbf{t}$ Ratio & Prob $>|\mathbf{t}|$ \\
\hline Intercept & 13.0011 & 8.4379 & 1.54 & 0.1247 \\
LN_CANADA & 0.0778 & 0.2710 & 0.29 & 0.7744 \\
LN_CHINA & -1.4954 & 0.4886 & -3.06 & $0.0025^{*}$ \\
LN_IRAN & -0.6239 & 0.2122 & -2.94 & $0.0036^{*}$ \\
LN_IRAQ & 0.1207 & 0.0527 & 2.29 & $0.023^{*}$ \\
LN_KUWAIT & -1.5579 & 0.5193 & -3.00 & $0.003^{*}$ \\
LN_OECDCON & -0.5698 & 0.5152 & -1.11 & 0.2698 \\
LN_OPEC & 0.1627 & 0.8836 & 0.18 & 0.8541 \\
LN_RUSSIA & 2.9632 & 0.3117 & 9.51 & $<0.0001^{*}$ \\
LN_SAUDI & 1.4614 & 0.4328 & 3.38 & $0.0009^{*}$ \\
LN_UAE & 0.3710 & 0.4805 & 0.77 & 0.4409 \\
LN_US & -0.2759 & 0.1981 & -1.39 & 0.165 \\
LN_USDX & -3.6848 & 0.2900 & -12.71 & $<0.0001$ * \\
RSquare & 0.90 & & & \\
\hline
\end{tabular}

Note: * represents statistical significance at a level of 0.1. $\mathrm{t}$ Ratio is defined as Estimate divided by Std Error to calculate $\mathrm{p}$-value, while RSquare represents the explained portion of variance by an independent variable.

In the analysis of the whole period, it is also worthwhile to note that the U.S. production, OECD consumption, or OPEC production have not influenced the BRENT price in a statistically significant way $(10 \%)$.

\subsection{Variability of Variables}

One of the ways to understand a system begins with knowledge of its variation, besides a system itself [42]. Coefficients of variations would represent how the variables experienced fluctuations over a specified period. Table 3 and Figure 5 present the coefficients of variations for each variable during each of the 36-month periods. BRENT price tops in the CV ranking in six periods of the total seven, except in Panel 2 (2001-2003) when Brent's CV of 13.1 is second to the IRAQ production variable with a CV of 40.5. BRENT price range over the 21 years is U\$123 per barrel, with a low of U\$10. IRAQ production has shown the most fluctuations among all the producers in all the past seven panels, as well as over the whole period. Over the whole period, IRAQ production tops with a CV of 35.0, followed by US (26.5), CANADA (25.4), and RUSSIA (16.8).

Table 3. Coefficients of variations for each of variables by panel.

\begin{tabular}{ccccccccc}
\hline Variable & Panel 1 & Panel 2 & Panel 3 & Panel 4 & Panel 5 & Panel 6 & Panel 7 & Whole \\
\hline & $(1998-2000)$ & $(2001-2003)$ & $(2004-2006)$ & $(2007-2009)$ & $(2010-2012)$ & $(2013-2015)$ & $(2016-2018)$ & $(1998-2018)$ \\
BRENT & 38.09 & 13.07 & 23.90 & 31.69 & 16.49 & 30.96 & 23.17 & 54.54 \\
CANADA & 3.09 & 6.13 & 4.96 & 3.36 & 7.51 & 6.41 & 9.24 & 25.41 \\
CHINA & 1.36 & 1.83 & 2.54 & 1.47 & 2.51 & 1.86 & 3.08 & 9.29 \\
IRAN & 3.90 & 4.67 & 1.86 & 1.90 & 9.57 & 2.75 & 7.11 & 10.10 \\
IRAQ & 19.09 & 40.48 & 9.19 & 7.88 & 10.48 & 13.92 & 3.11 & 35.05 \\
KUWAIT & 5.92 & 6.56 & 3.48 & 4.25 & 6.20 & 2.93 & 2.87 & 12.66 \\
OECDCON & 3.31 & 2.35 & 2.40 & 3.81 & 2.10 & 1.72 & 1.76 & 3.84 \\
OPEC & 3.70 & 3.90 & 2.53 & 2.80 & 2.34 & 2.47 & 1.15 \\
RUSSIA & 4.74 & 7.43 & 2.73 & 0.98 & 1.24 & 1.10 & 1.79 & 7.43 \\
SAUDI & 4.93 & 7.18 & 4.08 & 5.42 & 5.49 & 3.49 & 2.43 & 9.58 \\
UAE & 4.86 & 6.08 & 4.43 & 5.20 & 6.59 & 3.33 & 3.07 & 13.55 \\
US & 3.91 & 2.43 & 5.93 & 5.07 & 8.63 & 10.33 & 10.54 & 26.52 \\
USDX & 2.21 & 3.30 & 2.37 & 4.67 & 2.59 & 6.95 & 2.66 \\
\hline
\end{tabular}




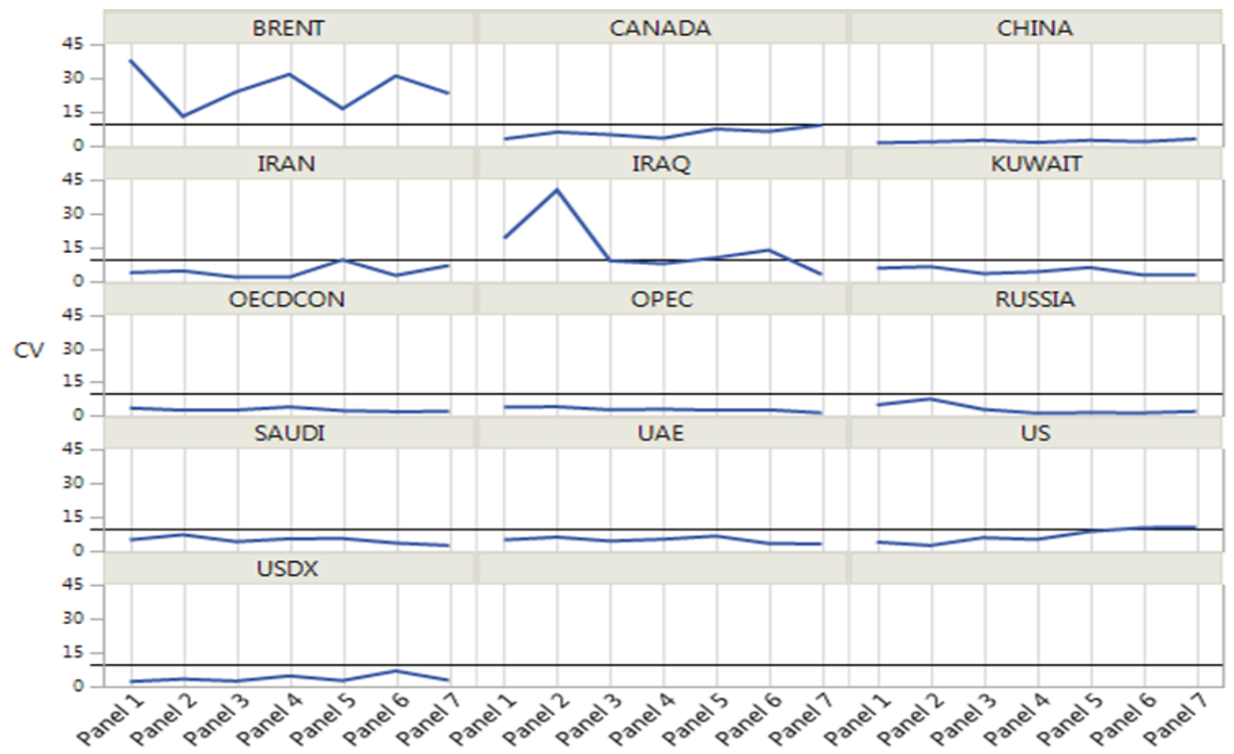

Figure 5. Coefficients of variations for each variable by panel. CV: coefficient of variable.

Table 4 is a summary of the top four crude oil-producing countries with high CVs in each panel period. Over the whole period (1998-2018), IRAQ production experienced the highest CV (IRAQ production and ranked first for most of the panels, except for a recent Panel 7 Period (2016-2018) when U.S. production takes the top position. U.S. production recorded the CVs over 10 in the past two panel periods, indicating a swing volume of ten percent or more in recent years. One observation is that CHINA, the world's top seventh oil producer, has maintained a low CV in each of the panels, implying the country is not an oil exporter but, rather, a domestic producer-consumer.

Table 4. Top four countries with the highest coefficients of variations for by panel.

\begin{tabular}{cccccc}
\hline Panel & Period & Rank 1 & Rank 2 & Rank 3 & Rank 4 \\
\hline Panel 1 & $(1998-2000)$ & IRAQ (19.1) & KUWAIT (5.9) & SAUDI (4.9) & UAE (4.9) \\
Panel 2 & $(2001-2003)$ & IRAQ (40.5) & RUSSIA (7.4) & SAUDI (7.2) & KUWAIT (6.6) \\
Panel 3 & $(2004-2006)$ & IRAQ (9.2) & US (5.9) & CANADA (5) & UAE (4.4) \\
Panel 4 & $(2007-2009)$ & IRAQ (7.9) & SAUDI (5.4) & UAE (5.2) & US (5.1) \\
Panel 5 & $(2010-2012)$ & IRAQ (10.5) & IRAN (9.6) & US (8.6) & CANADA (7.5) \\
Panel 6 & $(2013-2015)$ & IRAQ (13.9) & US (10.3) & USDX (6.9) & CANADA (6.4) \\
Panel 7 & $(2016-2018)$ & US (10.5) & CANADA (9.2) & IRAN (7.1) & IRAQ (3.1) \\
Whole & $(1998-2018)$ & IRAQ (35) & US (26.5) & CANADA (25.4) & RUSSIA (16.8) \\
\hline
\end{tabular}

\subsection{Panel 1: 1998 to 2000}

Panel 1 Period covers 36 months in 1998 to 2000, with an average BRENT price of U\$19.72 per barrel. BRENT shows the highest CV (38.09), and the producers with high CVs are IRAQ (19.09), KUWAIT (5.92), SAUDI (4.93), and UAE (4.86) (Table 5). Among the producers, IRAQ production is the most fluctuating in this period, while the US and OPEC look stable in their production volume. BRENT price range is U\$23 per barrel, with a low of U\$10.

A summary of parameter estimates in Table 6 shows that RUSSIA is the only statistically significant variable at a level of $10 \%$, with none of the producers significant. RUSSIA production exerted influence on BRENT prices in a co-move or $1 \%$ change in RUSSIA production leading to $10.31 \%$ in BRENT prices. This could be counter-intuitive in the economic sense because of the usual negative relationship between supply volume and a market price. One interpretation is RUSSIA took a good timing of the oil market, and their additional significant volume did not push down the market price or vice versa. 
This panel period corresponds to the events of the Asian financial crisis (1997-1998) and Operation Desert Fox, a 4-day bombing campaign on Iraq targets.

Table 5. Panel 1 period (1998-2000): summary statistics.

\begin{tabular}{ccccccccc}
\hline Variable & N & Mean & Median & Std Dev & CV & Min & Max & Range \\
\hline BRENT & 36 & 19.72 & 17.47 & 7.51 & 38.09 & 9.82 & 33.14 & 23.32 \\
CANADA & 36 & 1955 & 1960 & 60 & 3.09 & 1832 & 2064 & 232 \\
CHINA & 36 & 3214 & 3213 & 44 & 1.36 & 3134 & 3300 & 166 \\
IRAN & 36 & 3630 & 3635 & 141 & 3.90 & 3415 & 3925 & 510 \\
IRAQ & 36 & 2410 & 2540 & 460 & 19.09 & 1261 & 3055 & 1794 \\
KUWAIT & 36 & 2021 & 2020 & 120 & 5.92 & 1785 & 2215 & 430 \\
OECDCON & 36 & 48,101 & 47,831 & 1593 & 3.31 & 44,411 & 52,101 & 7690 \\
OPEC & 36 & 28,188 & 28,120 & 1043 & 3.70 & 25,956 & 30,282 & 4326 \\
RUSSIA & 36 & 6137 & 6088 & 291 & 4.74 & 5707 & 6771 & 1064 \\
SAUDI & 36 & 8210 & 8187 & 405 & 4.93 & 7610 & 8975 & 1365 \\
UAE & 36 & 2295 & 2300 & 111 & 4.86 & 2105 & 2480 & 375 \\
US & 36 & 5985 & 5885 & 234 & 3.91 & 5739 & 6541 & 802 \\
USDX & 36 & 117 & 117 & 3 & 2.21 & 114 & 124 & 10 \\
\hline
\end{tabular}

Table 6. Panel 1 period (1998-2000): LN_BRENT prediction-parameter estimation.

\begin{tabular}{ccccc}
\hline Variable & Estimate & Std Error & t Ratio & Prob $>|\mathbf{t}|$ \\
\hline Intercept & -75.3176 & 55.9357 & -1.35 & 0.1913 \\
LN_CANADA & 1.0698 & 1.3973 & 0.77 & 0.4517 \\
LN_CHINA & 2.3875 & 2.9872 & 0.8 & 0.4323 \\
LN_IRAN & -1.4313 & 1.7139 & -0.84 & 0.4122 \\
LN_IRAQ & 0.0774 & 0.6667 & 0.12 & 0.9086 \\
LN_KUWAIT & 0.4467 & 2.6488 & 0.17 & 0.8676 \\
LN_OECDCON & -1.7855 & 1.2473 & -1.43 & 0.1657 \\
LN_OPEC & 0.2553 & 9.6455 & 0.03 & 0.9791 \\
LN_RUSSIA & 10.3123 & 1.8497 & 5.58 & $<0.0001$ * \\
LN_SAUDI & -0.0967 & 3.5770 & -0.03 & 0.9787 \\
LN_UAE & -1.3004 & 2.2682 & -0.57 & 0.572 \\
LN_US & 1.7922 & 2.4417 & 0.73 & 0.4704 \\
LN_USDX & -4.0685 & 2.5809 & -1.58 & 0.1286 \\
RSquare & 0.87 & & & \\
\hline
\end{tabular}

Note: * represents statistical significance at a level of 0.1 .

\subsection{Panel 2: in 2001 to 2003}

Panel 2 period has an average BRENT price of U\$26.10 per barrel, up about U $\$ 6$ from the Panel 1 period. BRENT has the second-highest CV (13.07) to IRAQ production (40.48), followed by producers RUSSIA (7.43), SAUDI (7.18), and KUWAIT (6.56) (Table 7). Among the producers, IRAQ production is still the most fluctuating in this period, and the US and OPEC still look stable in their production volume, with CVs of the 2.40-3.90 range. BRENT price range is U\$14 per barrel, with a low of U\$19.

A summary of parameter estimates in Table 8 presents that five producers/organizations are influencers to BRENT prices in this period at a significance level of 10\%: IRAQ, OPEC, CHINA, SAUDI, and the U.S. Negative price influencers are OPEC and the U.S., with the effects of $3.15 \%$ and $1.84 \%$, respectively, by one percent change in their production. Co-move price influencers with their production are CHINA, SAUDI, and IRAQ, with the effects of $2.98 \%, 1.86 \%$, and $0.16 \%$, respectively, by one percent change in production. This period includes the U.S. recovery time from March 2001. 
Table 7. Panel 2 period (2001-2003): summary statistics.

\begin{tabular}{ccccccccc}
\hline Variable & N & Mean & Median & Std Dev & CV & Min & Max & Range \\
\hline BRENT & 36 & 26.10 & 25.80 & 3.41 & 13.07 & 18.71 & 32.77 & 14.06 \\
CANADA & 36 & 2168 & 2166 & 133 & 6.13 & 1953 & 2480 & 527 \\
CHINA & 36 & 3366 & 3371 & 62 & 1.83 & 3220 & 3490 & 270 \\
IRAN & 36 & 3637 & 3692 & 170 & 4.67 & 3365 & 3935 & 570 \\
IRAQ & 36 & 1909 & 1969 & 773 & 40.48 & 53 & 2879 & 2826 \\
KUWAIT & 36 & 2009 & 1976 & 132 & 6.56 & 1803 & 2354 & 551 \\
OECDCON & 36 & 48,729 & 48,792 & 1144 & 2.35 & 46,491 & 51,589 & 5098 \\
OPEC & 36 & 27,479 & 27,631 & 1071 & 3.90 & 25,256 & 29,433 & 4177 \\
RUSSIA & 36 & 7485 & 7434 & 556 & 7.43 & 6680 & 8448 & 1768 \\
SAUDI & 36 & 8146 & 8060 & 585 & 7.18 & 7210 & 9521 & 2311 \\
UAE & 36 & 2212 & 2195 & 135 & 6.08 & 2050 & 2450 & 400 \\
US & 36 & 5732 & 5753 & 140 & 2.43 & 5358 & 5905 & 547 \\
USDX & 36 & 124 & 126 & 4 & 3.30 & 114 & 130 & 15 \\
\hline
\end{tabular}

Table 8. Panel 2 period (2001-2003): LN_BRENT prediction-parameter estimation.

\begin{tabular}{ccccc}
\hline Variable & Estimate & Std Error & t Ratio & Prob $>|\mathbf{t}|$ \\
\hline Intercept & 10.1815 & 26.0803 & 0.39 & 0.6998 \\
LN_CANADA & 0.6510 & 0.9991 & 0.65 & 0.5211 \\
LN_CHINA & 2.9807 & 1.4067 & 2.12 & 0.0451 * \\
LN_IRAN & 1.5051 & 1.0922 & 1.38 & 0.1815 \\
LN_IRAQ & 0.1644 & 0.0420 & 3.91 & 0.0007 * \\
LN_KUWAIT & 0.4455 & 0.9480 & 0.47 & 0.6429 \\
LN_OECDCON & -1.4286 & 0.8767 & -1.63 & 0.1168 \\
LN_OPEC & -3.1486 & 0.9435 & -3.34 & $0.0029 *$ \\
LN_RUSSIA & -0.8248 & 1.0001 & -0.82 & 0.418 \\
LN_SAUDI & 1.8548 & 0.8840 & 2.1 & $0.0471 *$ \\
LN_UAE & 0.1352 & 1.3897 & 0.1 & 0.9233 \\
LN_US & -1.8395 & 0.9814 & -1.87 & $0.0736 *$ \\
LN_USDX & 0.0125 & 1.4004 & 0.01 & 0.993 \\
RSquare & 0.76 & & & \\
\hline
\end{tabular}

\subsection{Panel 3: 2004 to 2006}

Panel 3 period sees a 50\% spike in an average BRENT price of U\$52.60 per barrel, up about U\$25 from the Panel 2 period. This period corresponds to the period when China and India were booming as emerging economies. BRENT regained the highest CV (23.90), followed again by IRAQ production (9.19) and U.S. (5.93), CANADA (4.96), and UAE (4.43) (Table 9). Among the producers, IRAQ production is still the most fluctuating in this period, and the U.S. came to play with a relatively volatile volume. BRENT price range is $\mathrm{U} \$ 43$ per barrel, with a low of $U \$ 31$.

A summary of parameter estimates in Table 10 shows that CHINA is the only producer statistically significant at a level of $10 \%$. However, CHINA is a co-move price influencer with the effect of $3.55 \%$ by one percent change in its production. However, OPEC and RUSSIA follow CHINA as potential price influencers, though the significance level is a little away at $11 \%$. This period is characterized by a growth theme in China and India. 
Table 9. Panel 3 period (2004-2006): summary statistics.

\begin{tabular}{ccccccccc}
\hline Variable & N & Mean & Median & Std Dev & CV & Min & Max & Range \\
\hline BRENT & 36 & 52.60 & 54.80 & 12.57 & 23.90 & 30.86 & 73.67 & 42.81 \\
CANADA & 36 & 2431 & 2411 & 121 & 4.96 & 2172 & 2669 & 497 \\
CHINA & 36 & 3589 & 3603 & 91 & 2.54 & 3393 & 3716 & 323 \\
IRAN & 36 & 4056 & 4035 & 76 & 1.86 & 3950 & 4230 & 280 \\
IRAQ & 36 & 1961 & 1903 & 180 & 9.19 & 1603 & 2303 & 700 \\
KUWAIT & 36 & 2480 & 2500 & 86 & 3.48 & 2300 & 2600 & 300 \\
OECDCON & 36 & 50,205 & 50,106 & 1207 & 2.40 & 47,433 & 52,782 & 5349 \\
OPEC & 36 & 31,217 & 31,448 & 791 & 2.53 & 29,368 & 32,382 & 3014 \\
RUSSIA & 36 & 9031 & 9028 & 247 & 2.73 & 8457 & 9450 & 993 \\
SAUDI & 36 & 9268 & 9500 & 378 & 4.08 & 8400 & 9600 & 1200 \\
UAE & 36 & 2550 & 2602 & 113 & 4.43 & 2220 & 2702 & 482 \\
US & 36 & 5237 & 5192 & 310 & 5.93 & 4214 & 5617 & 1403 \\
USDX & 36 & 111 & 111 & 3 & 2.37 & 107 & 117 & 10 \\
\hline
\end{tabular}

Table 10. Panel 3 period (2004-2006): LN_BRENT prediction-parameter estimation.

\begin{tabular}{ccccc}
\hline Variable & Estimate & Std Error & t Ratio & Prob $>|\mathbf{t}|$ \\
\hline Intercept & -76.7298 & 23.1602 & -3.31 & $0.003 *$ \\
LN_CANADA & -0.4416 & 0.5312 & -0.83 & 0.4144 \\
LN_CHINA & 3.5469 & 1.2921 & 2.75 & $0.0115^{*}$ \\
LN_IRAN & -3.3315 & 2.1477 & -1.55 & 0.1345 \\
LN_IRAQ & -0.5150 & 0.4697 & -1.1 & 0.2842 \\
LN_KUWAIT & -0.6316 & 2.1740 & -0.29 & 0.774 \\
LN_OECDCON & -0.8209 & 0.6835 & -1.2 & 0.2419 \\
LN_OPEC & 11.1122 & 6.7097 & 1.66 & 0.1113 \\
LN_RUSSIA & 1.9980 & 1.2326 & 1.62 & 0.1187 \\
LN_SAUDI & -3.5561 & 2.3156 & -1.54 & 0.1383 \\
LN_UAE & -0.3896 & 0.7672 & -0.51 & 0.6164 \\
LN_US & 0.0905 & 0.3718 & 0.24 & 0.8099 \\
LN_USDX & 0.4339 & 1.4334 & 0.3 & 0.7648 \\
RSquare & 0.94 & & & \\
\multicolumn{2}{c}{ Note ${ }^{*}$ represents statistical significance at a level of 0.1.} &
\end{tabular}

\subsection{Panel 4: 2007 to 2009}

Panel 4 period sees a 30\% lift in an average BRENT price of U $\$ 76.93$ per barrel, about U $\$ 24$ from the Panel 3 period. This period corresponds to the period when China and India continued growing. BRENT is still fluctuating with the highest CV (31.69), followed by again IRAQ production (7.88) and SAUDI (5.42), UAE (5.2), and U.S. (5.07) (Table 11). Among the producers, the U.S. comes to play with a relatively volatile volume, with IRAQ, SAUDI, and UAE. BRENT price range is U\$93 per barrel, with a low of U\$40.

A summary of parameter estimates in Table 12 displays that two macro-variables (USDX and OECDCON) and two producers are BRENT influencers in this period, at a significance level of $10 \%$. Negative price influencers are USDX, IRAN, and OECDCON, with the effects of $4.79 \%, 3.76 \%$, and $1.72 \%$, respectively, by one percent change in their production or index. Co-move price influencers include SAUDI, with the effects of $3.89 \%$, by one percent change in production. This period is still characterized by a growth theme in China and India, which caused the WTI future's price to spike to an unprecedented U\$150 per barrel in August 2008. 
Table 11. Panel 4 period (2007-2009): summary statistics.

\begin{tabular}{ccccccccc}
\hline Variable & N & Mean & Median & Std Dev & CV & Min & Max & Range \\
\hline BRENT & 36 & 76.93 & 72.05 & 24.38 & 31.69 & 39.95 & 132.72 & 92.77 \\
CANADA & 36 & 2596 & 2593 & 87 & 3.36 & 2436 & 2809 & 373 \\
CHINA & 36 & 3774 & 3775 & 56 & 1.47 & 3643 & 3884 & 241 \\
IRAN & 36 & 3999 & 4000 & 76 & 1.90 & 3900 & 4100 & 200 \\
IRAQ & 36 & 2284 & 2353 & 180 & 7.88 & 1753 & 2505 & 752 \\
KUWAIT & 36 & 2467 & 2448 & 105 & 4.25 & 2350 & 2629 & 279 \\
OECDCON & 36 & 48,206 & 48,275 & 1838 & 3.81 & 44,239 & 51,491 & 7252 \\
OPEC & 36 & 31,496 & 31,105 & 880 & 2.80 & 30,335 & 33,191 & 2856 \\
RUSSIA & 36 & 9430 & 9415 & 93 & 0.98 & 9296 & 9654 & 358 \\
SAUDI & 36 & 8743 & 8600 & 474 & 5.42 & 8068 & 9700 & 1632 \\
UAE & 36 & 2661 & 2612 & 138 & 5.20 & 2242 & 2850 & 608 \\
US & 36 & 5140 & 5141 & 261 & 5.07 & 3974 & 5555 & 1581 \\
USDX & 36 & 103 & 103 & 5 & 4.67 & 95 & 112 & 17 \\
\hline
\end{tabular}

Table 12. Panel 4 period (2007-2009): LN_BRENT prediction-parameter estimation.

\begin{tabular}{ccccc}
\hline Variable & Estimate & Std Error & t Ratio & Prob $>|\mathbf{t}|$ \\
\hline Intercept & 43.3000 & 23.1744 & 1.87 & $0.0745^{*}$ \\
LN_CANADA & -0.2797 & 0.3697 & -0.76 & 0.457 \\
LN_CHINA & 0.7812 & 1.2245 & 0.64 & 0.5298 \\
LN_IRAN & -3.7626 & 1.1971 & -3.14 & $0.0046^{*}$ \\
LN_IRAQ & 0.2652 & 0.3597 & 0.74 & 0.4684 \\
LN_KUWAIT & -0.1553 & 1.6641 & -0.09 & 0.9265 \\
LN_OECDCON & -1.7258 & 0.7941 & -2.17 & $0.0403 *$ \\
LN_OPEC & -3.2596 & 3.4539 & -0.94 & 0.3551 \\
LN_RUSSIA & 2.8192 & 1.9612 & 1.44 & 0.164 \\
LN_SAUDI & 3.8902 & 1.0800 & 3.6 & $0.0015^{*}$ \\
LN_UAE & 0.2585 & 0.3869 & 0.67 & 0.5107 \\
LN_US & -0.1685 & 0.3369 & -0.5 & 0.6218 \\
LN_USDX & -4.7920 & 0.4936 & -9.71 & $<0.0001 *$ \\
RSquare & 0.97 & & & \\
\multicolumn{5}{c}{ Note: * represents statistical significance at a level of 0.1.} \\
\end{tabular}

\subsection{Panel 5: 2010 to 2012}

Panel 5 period also experiences a 25\% spike to an average BRENT price of U\$100.81 per barrel, up about U\$24 from Panel 4 period. This period corresponds to the one with major events, such as Arab Spring and European Debt Crisis, in Portugal, Italy, Iceland, and Greece. BRENT still tops the CV (16.49) but lower from the CV of the previous period (31.69), followed by again IRAQ production (7.88) and IRAN (10.48), U.S. (8.63), and CANADA (7.51) (Table 13). U.S., IRAN, and CANADA were actively participating in the additions of oil supply with the prices moving higher. The U.S. shale oil and Canada oil sands play significant roles. BRENT price range is U $\$ 52$ per barrel, with a low of U $\$ 74$. 
Table 13. Panel 5 period (2010-2012): summary statistics.

\begin{tabular}{ccccccccc}
\hline Variable & N & Mean & Median & Std Dev & CV & Min & Max & Range \\
\hline BRENT & 36 & 100.81 & 109.28 & 16.62 & 16.49 & 73.75 & 125.45 & 51.70 \\
CANADA & 36 & 2926 & 2968 & 220 & 7.51 & 2484 & 3427 & 943 \\
CHINA & 36 & 4068 & 4055 & 102 & 2.51 & 3891 & 4281 & 390 \\
IRAN & 36 & 3841 & 4049 & 368 & 9.57 & 3018 & 4127 & 1109 \\
IRAQ & 36 & 2669 & 2600 & 280 & 10.48 & 2325 & 3275 & 950 \\
KUWAIT & 36 & 2488 & 2550 & 154 & 6.20 & 2250 & 2650 & 400 \\
OECDCON & 36 & 46,323 & 46,354 & 971 & 2.10 & 44,486 & 48,361 & 3875 \\
OPEC & 36 & 32,000 & 31,967 & 750 & 2.34 & 30,585 & 33,409 & 2824 \\
RUSSIA & 36 & 9796 & 9806 & 121 & 1.24 & 9557 & 10048 & 491 \\
SAUDI & 36 & 9396 & 9440 & 515 & 5.49 & 8240 & 10040 & 1800 \\
UAE & 36 & 2804 & 2890 & 185 & 6.59 & 2570 & 3010 & 440 \\
US & 36 & 5877 & 5613 & 507 & 8.63 & 5299 & 7088 & 1789 \\
USDX & 36 & 100 & 99 & 3 & 2.59 & 95 & 105 & 10 \\
\hline
\end{tabular}

A summary of parameter estimates in Table 14 displays that there are four significant factors: one macro-variable (USDX) and three producers: UAE, CANADA, and IRAN. Under the average price of U\$100 per barrel this period, the only negative price influencer is USDX, with an effect of $2.29 \%$ by one percent change in the index strength, while UAE, CANADA, and IRAN exert, as co-move influencers, the effects of $3.27 \%, 0.47 \%$, and $0.5 \%$, respectively, by one percent change in their production. This period is characterized by continued price spikes. The co-move influencers may not able to lower the prices by adding supplies, failing to turn the economic theory to work.

Table 14. Panel 5 period (2010-2012): LN_BRENT prediction-parameter estimation.

\begin{tabular}{ccccc}
\hline Variable & Estimate & Std Error & t Ratio & Prob $>|\mathbf{t}|$ \\
\hline Intercept & -24.2252 & 19.1291 & -1.27 & 0.218 \\
LN_CANADA & 0.4716 & 0.2284 & 2.07 & $0.0504^{*}$ \\
LN_CHINA & 0.6489 & 0.4588 & 1.41 & 0.1707 \\
LN_IRAN & 0.5004 & 0.2903 & 1.72 & $0.0982 *$ \\
LN_IRAQ & -0.1679 & 0.3016 & -0.56 & 0.5831 \\
LN_KUWAIT & -0.5369 & 0.7518 & -0.71 & 0.4824 \\
LN_OECDCON & 0.4828 & 0.5913 & 0.82 & 0.4226 \\
LN_OPEC & 1.3692 & 0.9356 & 1.46 & 0.1569 \\
LN_RUSSIA & -0.6539 & 1.2249 & -0.53 & 0.5986 \\
LN_SAUDI & -0.7222 & 0.5973 & -1.21 & 0.2389 \\
LN_UAE & 3.2733 & 0.7638 & 4.29 & $0.0003 *$ \\
LN_US & -0.1340 & 0.4333 & -0.31 & 0.7599 \\
LN_USDX & -2.2889 & 0.6903 & -3.32 & $0.003 *$ \\
RSquare & 0.96 & & & \\
\hline
\end{tabular}

Note: * represents statistical significance at a level of 0.1 .

\subsection{Panel 6: 2013 to 2015}

Panel 6 period underwent a price decline mode with an average BRENT price of U\$86.67 per barrel, now down about $\mathrm{U} \$ 13$ from the Panel 5 period. This period corresponds to the one when oil supply glut and slow growth in the Chinese economy were observed. BRENT still tops the CV (30.96) but back up from the CV of the previous period (16.49), followed by again IRAQ production (13.92) and U.S. (10.33), CANADA (6.41), and SAUDI (3.49) (Table 15). The U.S. and CANADA continue to be active producers in the global oil market. The U.S. shale oil and Canada oil sands play significant roles. BRENT price range is U\$78 per barrel, with a low of U\$38. 
Table 15. Panel 6 period (2013-2015): summary statistics.

\begin{tabular}{ccccccccc}
\hline Variable & $\mathbf{N}$ & Mean & Median & Std Dev & $\mathbf{C V}$ & Min & Max & Range \\
\hline BRENT & 36 & 86.67 & 102.41 & 26.83 & 30.96 & 38.01 & 116.05 & 78.04 \\
CANADA & 36 & 3538 & 3548 & 227 & 6.41 & 3026 & 3922 & 896 \\
CHINA & 36 & 4217 & 4225 & 78 & 1.86 & 4040 & 4408 & 368 \\
IRAN & 36 & 3215 & 3230 & 88 & 2.75 & 3064 & 3389 & 325 \\
IRAQ & 36 & 3488 & 3325 & 486 & 13.92 & 2825 & 4416 & 1591 \\
KUWAIT & 36 & 2692 & 2650 & 79 & 2.93 & 2550 & 2880 & 330 \\
OECDCON & 36 & 45,960 & 45,933 & 789 & 1.72 & 44,250 & 47,862 & 3612 \\
OPEC & 36 & 32,206 & 32,083 & 794 & 2.47 & 30,980 & 33,616 & 2636 \\
RUSSIA & 36 & 10,137 & 10,110 & 111 & 1.10 & 9955 & 10,407 & 452 \\
SAUDI & 36 & 9864 & 9840 & 344 & 3.49 & 9140 & 10,490 & 1350 \\
UAE & 36 & 3032 & 3026 & 101 & 3.33 & 2836 & 3190 & 354 \\
US & 36 & 8551 & 8750 & 884 & 10.33 & 7025 & 9650 & 2625 \\
USDX & 36 & 107 & 103 & 7 & 6.95 & 99 & 122 & 23 \\
\hline
\end{tabular}

A summary of parameter estimates in Table 16 displays that there are two significant factors: one macro-variable (USDX) and the only producer SAUDI. Under the average price of U\$87 per barrel this period, the only negative price influencer is USDX, with an effect of $6.03 \%$ by one percent change in the index strength, while SAUDI exerts, as a co-move influencer, an effect of $1.83 \%$, by one percent change in their production. This period is characterized by a downward price trend, with the U.S. and Canada increasing the production.

Table 16. Panel 6 period (2013-2015): LN_BRENT prediction-parameter estimation.

\begin{tabular}{ccccc}
\hline Variable & Estimate & Std Error & t Ratio & Prob $>|\mathbf{t}|$ \\
\hline Intercept & 38.1038 & 29.3481 & 1.3 & 0.207 \\
LN_CANADA & -0.1507 & 0.3298 & -0.46 & 0.652 \\
LN_CHINA & -0.3178 & 0.8719 & -0.36 & 0.7188 \\
LN_IRAN & 1.1216 & 0.9468 & 1.18 & 0.2482 \\
LN_IRAQ & 0.4410 & 0.3328 & 1.33 & 0.1981 \\
LN_KUWAIT & -0.5086 & 1.3276 & -0.38 & 0.7052 \\
LN_OECDCON & 0.2343 & 0.8602 & 0.27 & 0.7877 \\
LN_OPEC & -1.5576 & 1.8365 & -0.85 & 0.4051 \\
LN_RUSSIA & -1.8185 & 2.5350 & -0.72 & 0.4804 \\
LN_SAUDI & 1.8321 & 0.5320 & 3.44 & $0.0022 *$ \\
LN_UAE & 0.4340 & 0.8341 & 0.52 & 0.6078 \\
LN_US & -0.0180 & 0.3033 & -0.06 & 0.9532 \\
LN_USDX & -6.0316 & 0.7167 & -8.42 & $<0.0001$ * \\
RSquare & 0.98 & & & \\
\hline
\end{tabular}

Note: ${ }^{*}$ represents statistical significance at a level of 0.1 .

\subsection{Panel 7: 2016 to 2018}

Panel 7 period continued a downward trend, with an average BRENT price of U\$56.29 per barrel, now collapsing about U\$30 from the Panel 6 period. This period corresponds to the one when oil supply glut and slow growth in the Chinese economy were seriously observed. The U.S. shale oil growth was remarkable in contributing to the growth of the oil supply. The shale production was close to zero in 2008 but grew to 4.25 million barrels per in 2016, standing with a $48 \%$ share of the U.S. oil production and $5 \%$ of the global production [10]. BRENT still tops the CV (23.27), followed by U.S. production (10.54) and CANADA (9.24), IRAN (7.11), and IRAQ (3.11) (Table 17). IRAQ showed the highest CV-producer position to the U.S., and the U.S. and CANADA continue to be active producers in the global oil market, with the U.S. shale oil and Canada oil sands. 
Table 17. Panel 7 period (2016-2018): summary statistics.

\begin{tabular}{ccccccccc}
\hline Variable & N & Mean & Median & Std Dev & CV & Min & Max & Range \\
\hline BRENT & 36 & 56.29 & 53.95 & 13.04 & 23.17 & 30.70 & 81.03 & 50.33 \\
CANADA & 36 & 3985 & 3993 & 368 & 9.24 & 2811 & 4520 & 1709 \\
CHINA & 36 & 3859 & 3827 & 119 & 3.08 & 3694 & 4166 & 472 \\
IRAN & 36 & 4291 & 4417 & 305 & 7.11 & 3351 & 4624 & 1273 \\
IRAQ & 36 & 4503 & 4475 & 140 & 3.11 & 4217 & 4815 & 598 \\
KUWAIT & 36 & 2821 & 2792 & 81 & 2.87 & 2681 & 2951 & 270 \\
OECDCON & 36 & 47,188 & 47,160 & 831 & 1.76 & 45,356 & 48,714 & 3358 \\
OPEC & 36 & 33,998 & 34,017 & 391 & 1.15 & 33,227 & 34,976 & 1749 \\
RUSSIA & 36 & 10,630 & 10,558 & 190 & 1.79 & 10,254 & 11,051 & 797 \\
SAUDI & 36 & 10,339 & 10,240 & 251 & 2.43 & 9992 & 11,045 & 1053 \\
UAE & 36 & 3211 & 3185 & 99 & 3.07 & 3025 & 3451 & 426 \\
US & 36 & 9713 & 9214 & 1023 & 10.54 & 8519 & 11,961 & 3442 \\
USDX & 36 & 122 & 122 & 3 & 2.66 & 117 & 129 & 11 \\
\hline
\end{tabular}

A summary of parameter estimates in Table 18 displays that there are six significant influencing producers/organizations: IRAN, U.S., SAUDI, OPEC, CHINA, and UAE. Under the declining average price of $U \$ 56$ per barrel this period, there are two negative price influencers and four co-move price influencers. Negative influencers are OPEC and CHINA, with the effects of $3.98 \%$ and $1.48 \%$, respectively, by one percent change in their production volume, while the co-move influencers are SAUDI, IRAN, US, and UAE, with the effects of $2.65 \%, 2.31 \%, 1.82 \%$, and $1.37 \%$, respectively, by one percent change in their production. This period is characterized by a downward price trend, with a low of $\mathrm{U} \$ 31$ per barrel and BRENT price range of $\mathrm{U} \$ 50$.

Table 18. Panel 7 period (2016-2018): LN_BRENT prediction-parameter estimation.

\begin{tabular}{ccccc}
\hline Variable & Estimate & Std Error & t Ratio & Prob $>|\mathbf{t}|$ \\
\hline Intercept & 0.1928 & 17.4762 & 0.01 & 0.9913 \\
LN_CANADA & -0.1381 & 0.2158 & -0.64 & 0.5283 \\
LN_CHINA & -1.4797 & 0.8041 & -1.84 & $0.0787^{*}$ \\
LN_IRAN & 2.3120 & 0.3141 & 7.36 & $<0.0001^{*}$ \\
LN_IRAQ & -0.2414 & 0.8582 & -0.28 & 0.781 \\
LN_KUWAIT & -0.3288 & 0.6797 & -0.48 & 0.6332 \\
LN_OECDCON & -1.4119 & 0.8919 & -1.58 & 0.1271 \\
LN_OPEC & -3.9778 & 1.6584 & -2.4 & $0.025^{*}$ \\
LN_RUSSIA & 0.6585 & 1.2600 & 0.52 & 0.6062 \\
LN_SAUDI & 2.6515 & 1.0254 & 2.59 & $0.0165 *$ \\
LN_UAE & 1.3743 & 0.7865 & 1.75 & $0.0939 *$ \\
LN_US & 1.8205 & 0.2571 & 7.08 & $<0.0001$ * \\
LN_USDX & 0.1597 & 0.7861 & 0.2 & 0.8408 \\
RSquare & 0.96 & & & \\
\hline
\end{tabular}

Note: * represents statistical significance at a level of 0.1 .

\subsection{Summary of Results from Seven Panel Periods}

In the $\mathrm{CV}$ approach to measure a level of fluctuations, the Brent oil price recorded the highest $\mathrm{CV}$ of 54.4 over the whole period of 21 years, among all the variables, and maintained a top position during most of the seven-panel periods. Among explanatory variables, Iraq (35) topped in the variability of the production volume, followed by the U.S. (26.5), Canada (25.4), and Russia (16.8), over the whole period and has held the position for all panel periods, except for the Panel 7 period, or 2016-2018, when the U.S. takes the top spot. Only the four countries that recorded a CV of 9.0 or above in each of the periods are Iraq, Iran, the U.S., and Canada, implying their capability to expand the production capacity, for the U.S. and Canada, or unstable production levels, for Iraq and Iran. 
The multivariate regression approach was used to estimate a percentage change in the Brent oil price with respect to a percentage change in explanatory variables. Figure 6 displays a behavior over time (BOT) chart of coefficient estimates of each variable for each panel period. The coefficient estimates are present only when a variable is statistically significant at the $10 \%$ level; otherwise, the estimates are treated as zero in the chart. The U.S. Dollar Index (USDX) has been shown as the most influencing variable on the Brent oil price, with a coefficient estimate of -3.68 , followed by Kuwait $(-1.56)$, China $(-1.5)$, and Iran $(-0.62)$, in its magnitude.

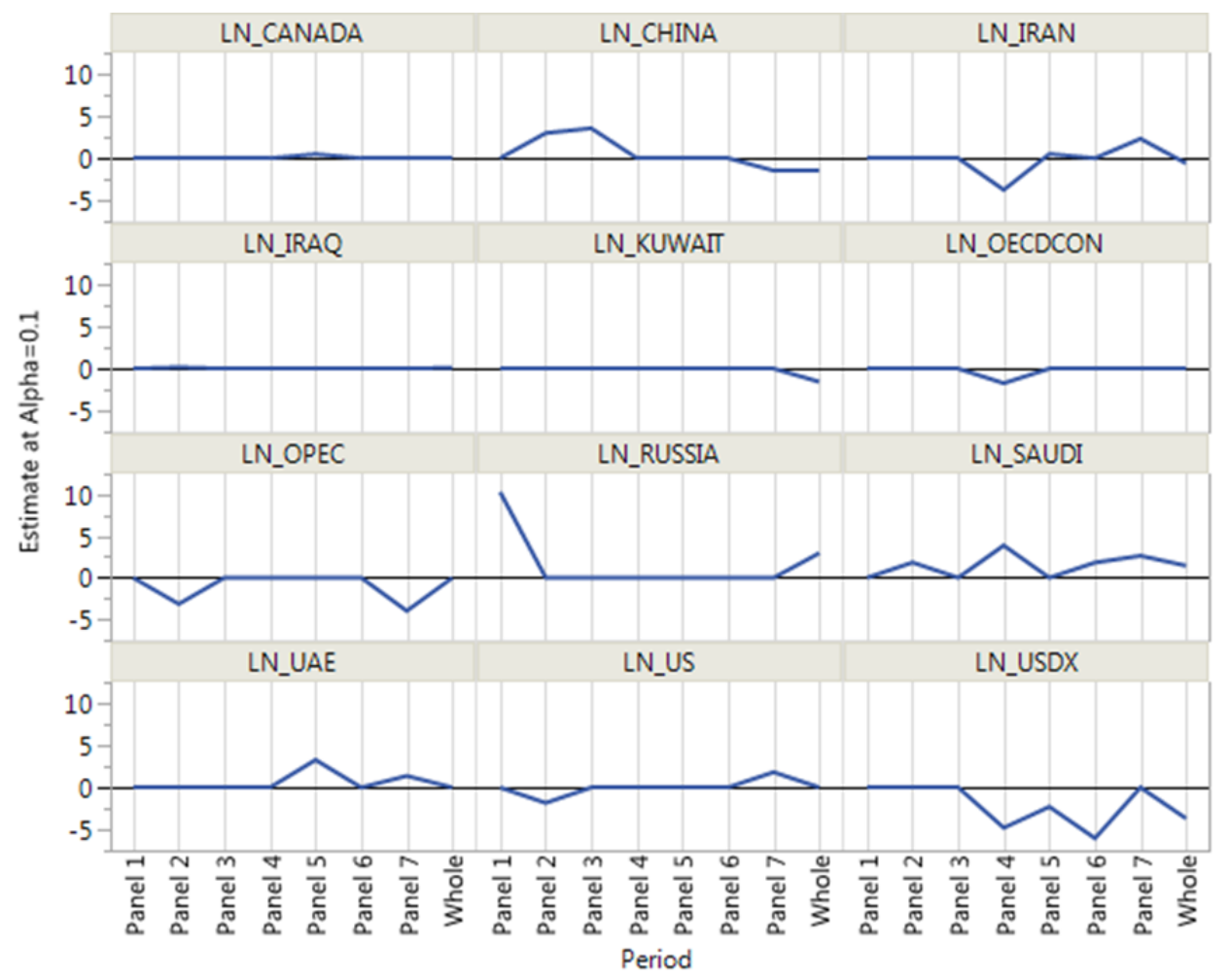

Figure 6. Coefficient estimates of variables by producer and panel at a significance level of 0.1.

In line with the economic theory that a negative relationship exists between production quantity and a market price, Table 19 presents a summary of negative impact ranks based on significant coefficients at the $10 \%$ level. From the analysis, OPEC was not the first influencer in all the seven panels but just in two panels, Panel 2 (2001-2003) and Panel 7 (2016-2018).

Table 19. Negative impact rank, based on significant coefficient estimates at the $10 \%$ level.

\begin{tabular}{cccccc}
\hline Panel & Period & Rank 1 & Rank 2 & Rank 3 & Rank 4 \\
\hline Panel 1 & $(1998-2000)$ & none significant & & & \\
Panel 2 & $(2001-2003)$ & OPEC $(-3.15)$ & US $(-1.84)$ & & \\
Panel 3 & $(2004-2006)$ & none significant & & & \\
Panel 4 & $(2007-2009)$ & USDX $(-4.79)$ & IRAN $(-3.76)$ & & \\
Panel 5 & $(2010-2012)$ & USDX $(-2.29)$ & & & \\
Panel 6 & $(2013-2015)$ & USDX (-6.03) & & & \\
Panel 7 & $(2016-2018)$ & OPEC (-3.98) & CHINA $(-1.48)$ & & \\
Whole & $(1998-2018)$ & USDX $(-3.68)$ & KUWAIT $(-1.56)$ & CHINA (-1.5) & IRAN $(-0.62)$ \\
\hline
\end{tabular}

While there were no significant influencing countries in Panel 1 (1998-2000) and Panel 3 (2004-2006), Panel 2 (2001-2003) has two influencers of OPEC (-3.15) and the U.S. (-1.84). In the other panels, USDX has appeared as the strongest influencer starting in Panel 4 (2007-2009), with -4.79, and then in 
Panel 5 (2010-2012), with -2.29, and, in Panel 6 (2013-2015), with -6.03. Panel 7 (2016-2018) records both OPEC and China as two most influencing producers, with -3.98 and -1.48 , respectively.

Contrary to the economic theory of production quantity and price, some oil producers' production quantities have shown a co-move relationship with the Brent oil price in some panel periods, indicating their increased production co-moved with higher prices or decreased production with lower prices. These producers include Russia, China, Saudi Arabia, UAE, Iran, and the U.S., with a coefficient estimate of positive 1.0 or greater, as shown in Table 20. China appeared with positive coefficients in Panel 2 (2001-2003) and Panel 3 (2007-2009) when there was a growing demand for energy due to their economic growth, and both Iran and the U.S. joined the co-move impact group in Panel 7 (2016-2018). Table 20 presents the co-move impact rank.

Table 20. Co-move impact rank, based on significant coefficient estimates at the $10 \%$ level.

\begin{tabular}{cccccc}
\hline Panel & Period & Rank 1 & Rank 2 & Rank 3 & Rank 4 \\
\hline Panel 1 & $(1998-2000)$ & RUSSIA (10.31) & & & \\
Panel 2 & $(2001-2003)$ & CHINA (2.98) & SAUDI (1.85) & IRAQ (0.16) & \\
Panel 3 & $(2004-2006)$ & CHINA (3.55) & & & \\
Panel 4 & $(2007-2009)$ & SAUDI (3.89) & & & \\
Panel 5 & $(2010-2012)$ & UAE (3.247) & IRAN (0.5) & CANADA (0.47) & \\
Panel 6 & $(2013-2015)$ & SAUDI (1.83) & & & UAE (1.37) \\
Panel 7 & $(2016-2018)$ & SAUDI (2.65) & IRAN (2.31) & US (1.82) & \\
Whole & $(1998-2018)$ & RUSSIA (2.96) & SAUDI (1.46) & IRAQ (0.12) & \\
\hline
\end{tabular}

\section{Conclusions and Policy Implications}

We investigated the relationships between Brent oil price and major producers' volumes to identify influencing weights of major crude oil producers in the world oil market, as well as those of petroleum consumption of OECD countries and the U.S. Dollar Index (USDX), with seven panels of 36 monthly data each across the years of 1998 to 2018. This paper is the first attempt to investigate the relationship between global oil price and major individual producing countries at three-year intervals for analysis over 21 years. The results will help energy policymakers understand the variability of oil market drivers in the specific time horizons and, in particular, the influences of the producing countries on world oil prices in the ever-evolving energy environment.

In the volatility measure of the $\mathrm{CV}$ (coefficient of variation), the $\mathrm{CV}$ of Brent oil price has been greater than any of the explanatory variables in all of the seven panel periods, while Iraq production, on the production side, has shown the highest $\mathrm{CV}$ among all the producers in the past six periods, but the U.S. later took the top position in Panel 7 (2016-2018). Iraq, the U.S., Iran, and Canada, with high CVs of 9.0 or greater, may have potentials to continue exerting significant influences on the global oil price. Surprisingly, the OPEC production volume was not as volatile as in the individual producers in the 21-year seven-panel history.

Parameter estimates from multivariate regression models for the seven panels showed that there had been various influencing producers in each of the seven panels, at the statistical significance level of $10 \%$, that have depressed the global oil price. OPEC appeared only twice in Panels 2 (2001-2003) and 7 (2016-2018), while the U.S., Iran, and China did once each. On the petroleum consumption side, OECD consumption also appeared once as a negative influencer in Panel 4 (2007-2009) when the crude oil price spiked to a $\$ 140 / \mathrm{bbl}$ level in 2008 . Notably, the U.S. Dollar Index (USDX), a macroeconomic variable, was the most prevalent influencer-three times in Panels 4, 5, and 6, or for 2007-2015. This result may be due to the fact that global oil is quoted and traded in U.S. dollars. Recent influencers in Panel 7 (2016-2018) were OPEC, the biggest producer in aggregate, and China.

We admit that there is a room for further researches to understand the dynamics of the global oil market. This paper focused on a panel of 36 months each, based on the assumption that a period of three years may be sufficient to bring a change to improve supply and demand situations in the oil markets, but with the advancement of technology, the panel period could be set shorter or longer for 
analysis, depending on the purpose of further research. Besides, as the OECD consumption in this paper is at the aggregate level of its member nations, further research may use individual nation's consumption data to investigate the influences of major/emerging economies in Europe, North America, and Asia.

Author Contributions: Conceptualization, P.Y.J.; Project administration, M.G.B.; Supervision, M.G.B.; Data curation, P.Y.J.; Formal analysis, P.Y.J.; Investigation, P.Y.J.; Methodology, P.Y.J.; Resources P.Y.J.; Software, P.Y.J.; Validation, P.Y.J. and M.G.B.; Visualization, P.Y.J. and M.G.B.; Writing - original draft, P.Y.J.; Writing- Reviewing and Editing, P.Y.J. and M.G.B. All authors have read and agreed to the published version of the manuscript.

Funding: This research received no external funding.

Conflicts of Interest: The authors declare no conflict of interest.

\section{References}

1. Hinrichs, R.A. Energy; Sanders College Publishing: New York, NY, USA, 1992; p. 2.

2. Gyagri, M.; Amarfio, E.M.; Marfo, S.A. Determinants of Global Pricing of Crude Oil-A Theoretical Review. Int. J. Pet. Petrochem. Eng. 2017, 3, 7-15.

3. Harraz, H.Z. Benchmarks of Crude Oils. Available online: https://www.researchgate.net/profile/Hassan Harraz/publication/301842929_BENCHMARKS_OF_CRUDE_OILS/links/572a065b08aef7c7e2c4ede8/ BENCHMARKS-OF-CRUDE-OILS.pdf (accessed on 9 June 2019).

4. Intercontinental Exchange. Oil Benchmarks: Implications \& Opportunities. Available online: https: //www.theice.com/publicdocs/Oil_Benchmarks_NY_May.pdf (accessed on 9 June 2019).

5. U.S. Energy Information Administration (EIA). Crude oils Have Different Quality Characteristics. Available online: https://www.eia.gov/todayinenergy/detail.php?id=7110 (accessed on 22 August 2019).

6. Strickler, G.; Plante, M.D. Modern Refineries, Shale Boom Upend Traditional Oil Price Relationships. Available online: https://www.dallasfed.org/research/economics/2019/0409 (accessed on 12 March 2020).

7. U.S. Energy Information Administration (EIA). Total Energy. 2019. Available online: https:/www.eia.gov/ totalenergy/data/annual/index.php (accessed on 25 June 2019).

8. Ellwanger, R.; Sawatzky, B.; Zmitrowicz, K. Factors behind the 2014 Oil Price Decline; European Central Bank: Frankfurt, Germany, 2017.

9. King, K.; Deng, A.; Metz, D. An Econometric Analysis of Oil Price Movements: The Role of Political Events and Economic News, Financial Trading, and Market Fundamentals; Bates White Economic Consulting: Washington, DC, USA, 2012.

10. Baffes, J.; Kose, M.A.; Ohnsorge, F.; Stocker, M. The Great Plunge in Oil Prices: Causes, Consequences, and Policy Responses. SSRN Electron. J. 2015. [CrossRef]

11. Sterman, J.D. Business Dynamics: Systems Thinking and Modeling for a Complex World; McGraw Hill: New York, NY, USA, 2000; pp. 108-117.

12. U.S. Energy Information Administration (EIA). Petroleum and Other Liquids. Available online: https: //www.eia.gov/dnav/pet/pet_pri_spt_s1_d.htm (accessed on 14 August 2019).

13. Hamilton, J.D. Historical Oil Shocks. In The Routledge Handbook of Major Events in Economic History; Routledge Taylor and Francis Group: New York, NY, USA, 2013; pp. 239-265.

14. Pierru, A.; Zamrik, T.; Smith, J.L. OPECs Impact on Oil Price Volatility: The Role of Spare Capacity. Energy J. 2018, 39. [CrossRef]

15. Dees, S.; Gasteuil, A.; Kaufmann, R.K.; Mann, M. Assessing the factors behind oil price changes. Eur. Central Bank Work. Pap. 2008, 1.

16. Katircioğlu, S.; Sertoglu, K.; Candemir, M.; Mercan, M. Oil price movements and macroeconomic performance: Evidence from twenty-six OECD countries. Renew. Sustain. Energy Rev. 2015, 44, 257-270. [CrossRef]

17. Ratti, R.A.; Vespignani, J. Oil prices and global factor macroeconomic variables. Energy Econ. 2016, 59, 198-212. [CrossRef]

18. Sek, S.K.; Teo, X.Q.; Wong, Y.N. A Comparative Study on the Effects of Oil Price Changes on Inflation. Procedia Econ. Finance 2015, 26, 630-636. [CrossRef]

19. Huang, S.; An, H.; Wen, S.; An, F. Revisiting driving factors of oil price shocks across time scales. Energy 2017, 139, 617-629. [CrossRef] 
20. Baumeister, C.; Kilian, L. Forty Years of Oil Price Fluctuations: Why the Price of Oil May Still Surprise Us. SSRN Electron. J. 2016, 30, 139-160.

21. OPEC. Member Countries. 2019. Available online: https://www.opec.org/opec_web/en/about_us/25.htm (accessed on 13 August 2019).

22. Yergin, D. The Prize: The Epic Quest for Oil, Money \& Power; Touchstone Simon \& Schuster: New York, NY, USA, 1992.

23. Ratti, R.A.; Vespignani, J. OPEC and non-OPEC oil production and the global economy. Energy Econ. 2015, 50, 364-378. [CrossRef]

24. Cologni, A.; Manera, M. On the Economic Determinants of Oil Production-Theoretical Analysis and Empirical Evidence for Small Exporting Countries. SSRN Electron. J. 2011, 68-79. [CrossRef]

25. Jang, P.Y.; Beruvides, M.G. OPEC: Systems Thinking on Low Oil Price Situation. In Proceedings of the ASEM 2019 International Annual Conference Proceedings, Philadelphia, PA, USA, 23-26 October 2019.

26. Kuhn, T.S. The Structure of Scientific Revolutions; University of Chicago Press: Chicago, IL, USA, 2012; pp. 11-84.

27. Fuinhas, J.A.; Marques, A.C.; Couto, A.P. Oil rents and economic growth in oil producing countries: Evidence from a macro panel. Econ. Chang. Restruct. 2015, 48, 257-279. [CrossRef]

28. Sotoudeh, M.A.; Worthington, A.C. Long-term effects of global oil price changes on the macroeconomy and financial markets: A comparative panel co-integration approach. Appl. Econ. Lett. 2014, 22, 960-966. [CrossRef]

29. Korhonen, I.; Ledyaeva, S. Trade linkages and macroeconomic effects of the price of oil. Energy Econ. 2010, 32, 848-856. [CrossRef]

30. Ederington, L.H.; Fernando, C.S.; Lee, T.K.; Linn, S.C.; May, A.D. Factors Influencing Oil Prices: A Survey of the Current State of Knowledge in the Context of the 2007-08 Oil Price Volatility. 2011. Available online: https://www.eia.gov/workingpapers/pdf/factors_influencing_oil_prices.pdf (accessed on 1 November 2019).

31. Robe, M.A.; Wallen, J. Fundamentals, Derivatives Market Information and Oil Price Volatility. SSRN Electron. J. 2014, 36, 317-344. [CrossRef]

32. Medlock, K.B. Speculation, Fundamentals, and the Price of Crude Oil; Baker III Institute for Public Policy of Rice University: Houston, TX, USA, 2013.

33. Wang, Q.; Sun, X. Crude oil price: Demand, supply, economic activity, economic policy uncertainty and wars-From the perspective of structural equation modelling (SEM). Energy 2017, 133, 483-490. [CrossRef]

34. Fueki, T.; Higashi, H.; Higashio, N.; Nakajima, J.; Ohyama, S.; Tamanyu, Y. Identifying Oil Price Shocks and Their Consequences: The Role of Expectations in the Crude Oil Market; Bank for International Settlements: Basel, Switzerland, 2018.

35. Hamilton, J.D. Oil and the Macroeconomy since World War II. J. Politi- Econ. 1983, 91, 228-248. [CrossRef]

36. Hou, K.; Mountain, D.C.; Wu, T. Oil price shocks and their transmission mechanism in an oil-exporting economy: A VAR analysis informed by a DSGE model. J. Int. Money Finance 2016, 68, 21-49. [CrossRef]

37. Hamdi, H.; Sbia, R. Dynamic relationships between oil revenues, government spending and economic growth in an oil-dependent economy. Econ. Model. 2013, 35, 118-125. [CrossRef]

38. Lorde, T.; Jackman, M.; Thomas, C. The macroeconomic effects of oil price fluctuations on a small open oil-producing country: The case of Trinidad and Tobago. Energy Policy 2009, 37, 2708-2716. [CrossRef]

39. El Anshasy, A.; Bradley, M.D. Oil prices and the fiscal policy response in oil-exporting countries. J. Policy Model. 2012, 34, 605-620. [CrossRef]

40. The Exploration and Production Life Cycle of Oil and Gas. Available online: www.reportingoilandgas.org/ the-exploration-and-production-life-cycle-of-oil-and-gas/ (accessed on 27 August 2019).

41. Lack, S. The Short Cycle Advantage of Shale. Forbes, 28 June 2018.

42. Deming, W.E. The New Economics for Industry, Government and Education; The MIT Press: Cambridge, MA, USA, 1994; pp. 98-100.

(C) 2020 by the authors. Licensee MDPI, Basel, Switzerland. This article is an open access article distributed under the terms and conditions of the Creative Commons Attribution (CC BY) license (http://creativecommons.org/licenses/by/4.0/). 